\title{
MIDDLE EAST AND NORTH AFRICA AS A PART OF CHINESE STRING OF PEARLS STRATEGY
}

\author{
Aghavni HARUTYUNYAN \\ Institute of Oriental Studies, \\ National Academy of Sciences of the Republic of Armenia, Armenia \\ E-mail: aghavni.harutyunyan1@gmail.com
}

\begin{abstract}
Launched by Chinese President Xi Jinping in 2013, the One Belt, One Road initiative (OBOR), which consists of land (EBSR) and sea routes (MSR), aims to connect Asia and Europe through the Middle East, Africa and Central Asia. The MSR strategy focuses on creating Chinese strongholds or "naval posts" with military or geopolitical influence along the Indian Ocean littoral, the Persian Gulf and the Mediterranean Sea, called a "String of Pearls" - similar to the "Dual Use Logistics Facility". It is related to Beijing's need for geostrategic security of the "choke points" and maritime [oil and trade] routes critical of its development and based on China's need to establish an increased level of influence and advanced presence along the sea routes through the use of investment, port development, economic, political, diplomatic and military means. China hopes to contribute to strengthening regional security on the southern gateway from the Indian Ocean to the Red Sea and the Suez Canal, one of the world's biggest shipping lanes and a pivotal part of the MSR. Today the Chinese energy security policy has been militarized by creating a navy and deploying troops to protect and implement energy and infrastructure projects in the Middle East and North Africa region. It is an important hub for the two OBOR routes due to its strategic location at the intersection of land and sea roads connecting Asia, Africa and Europe, and the three most important economic maritime regions: the South China Sea, the Persian Gulf, and the Mediterranean Sea.
\end{abstract}

KEYWORDS: China, OBOR, MSR, MENA, "String of Pearls”, "Dual Use Logistics Facility”, PLAN

\section{Introduction}

The Chinese strategy of the New Silk Road (One Belt, One Road) ${ }^{1}$, which consists of land and sea routes, is the abbreviated name of the double concept of the Economic Belt of the Silk Road (EBSR) and the Maritime Silk Road of the $21^{\text {st }}$ Century (MSR). It was launched by the President of the People's Republic of China (PRC) Xi Jinping in 2013 and aims to connect Asia and Europe via the Middle East (ME), Africa and Central Asia (CA) through a series of vast networks of transcontinental railways, pipelines, ports, airports, and other infrastructure projects with up to US \$ 1 trillion of Chinese investment (Molavi, 2018).

The idea of establishing the MSR was revealed during the Chinese Premier Li Keqiang's attendance at the $16^{\text {th }}$ ASEAN+China Summit in Brunei (9-10 October, 2013), and Xi Jinping's speech in the Indonesian parliament (3 October, 2013) (Szczudlik-Tatar, 2013, p. 3). The MSR will complement the EBSR by connecting Chinese ports to other countries via maritime links, focusing on the use of sea routes and Chinese coastal ports (BDO, 2015, p. 4) ${ }^{2}$ in order to connect China with Europe via the South China Sea, ${ }^{3}$ the Straits of Malacca, Lombok, Sudan and along the north Indian Ocean to the Persian Gulf, the Red Sea and the Gulf of Aden encompassing South and Southeast Asia, particularly Sri Lanka. Thus, the MSR will extend from Asia to the Near East, the Middle East and North Africa (MENA), East Africa, the Mediterranean, and Europe (Clemens, 2015, p. 6).

The first policy documents outlining the shape of China-MENA cooperation in the BRI framework was the "Vision and Actions on Jointly Building Silk Road Economic Belt and $21^{\text {st }}$-Century Maritime Silk Road" published by the Chinese government in March 2015. It describes plans for how the Belt will link China to the Persian Gulf and the Mediterranean Sea through CA and West Asia (passing through Gwadar, Istanbul and Tehran, and through Afghanistan, Iraq, Iran and Turkey) and

\footnotetext{
1 "One Belt, One Road" (OBOR) or Belt and Road Initiative (BRI/B\&R) or New Silk Road (NSR).

${ }^{2}$ The EBSR focuses on connecting China to Europe through Central Asia and Russia, the Persian Gulf through Central Asia and South East Asia, South Asia and the Indian Ocean.

${ }^{3}$ Control over the South China Sea is one of the milestones in the Chinese strategy for dominance. The sea itself is one of the busiest commercial routes and the shortest possible way that connects the West Pacific/East Asia with the Indian Ocean, Africa, and Europe. It also provides direct access to nine of the ten largest commercial ports in the world. Seven of them are Chinese, including Hong Kong and the other two are Busan in South Korea and Taiwan.
} 
how the Road will connect China's South China Sea all the way to the Mediterranean via the Indian Ocean, the Gulf of Aden, the Red Sea and the Suez Canal (Harutyunyan, 2019, p. 32).

MSR targets key littoral states along major Indian Ocean trade arteries for the construction of OBOR's two mega-projects - the land-based CPEC $C^{4}$ and the sea-based BCIM-EC $C^{5}$, which, with large investments from China, can fundamentally change the political and economic landscape of the Indian Ocean Region (IOR) (Zhou, 2014). IOR is one of the most strategically significant in a world, which has become a friction point of tension between the United States (U.S.), China, and India, and where China and India are fighting for superiority over sea lines. Such tension intensifies as each state takes measures to counter the others and project dominance within the region (Abeyagoonasekera, 2019, p. 48).

\section{The Chinese Strategy of "String of Pearls" and "Dual Use Logistics Facility"}

The Indian Ocean has an impressive number of shipping lines, also known as Sea Lines of Communication (SLOCs) - sea passages between ports. Given that over $90 \%$ of the world trade is shipping, these SLOCs have great geopolitical value, since the country that controls them can either open or restrict their access (Mahan, 2019, p. 2). The Indian Ocean is also the home of China's important SLOCs, thus raising the stakes for China to maintain security and stability in the IOR to avoid any instances of being choked (Jash, 2018, p. 73). Since the Indian Ocean is considered to be part of the farseas, it provides conditions for the Chinese People's Liberation Army Navy (PLAN) to navigate and operate in a deep-water region (Payette, Sun, 2017, p. 5). The most critical interest is China's energy "life line", passing through the IOR and, to a large extent, constituting its "strategic vulnerability" from the ban on the part of the U.S. or India. This makes the defense of its SLOC one of the most important functions of the PLAN missions in the IOR and reinforces the need for China's continued presence in the naval forces in the IOR (Khurana, 2018, p. 201). The modernization and expansion of PLAN's presence in the IOR offers China more opportunities to build more bases abroad serving PLAN, gain valuable work experience away from home, and also strengthen and improve China's ability to project geopolitical power (Payette, Sun, 2017, p. 16).

In this context, the strategy of the Beijing MSR is of great interest, which focuses on creating Chinese strongholds or "naval posts" with military or geopolitical influence along the Indian Ocean littoral, the Persian Gulf, and the Mediterranean Sea, called a "String of Pearls" - similar to the "Dual Use Logistics Facility" (Lin, 2011, p. 10). Beijing began work on projects for the "Dual Use Logistics Facility", which should make up the "String of Pearls", at the end of the $20^{\text {th }}$ century and continues to this day. The "Dual Use Logistics Facility" is characterized by its light footprint, its emphasis on providing logistics support to overseas non-traditional security missions, and its dual commercial and military nature. The "String of Pearls" model is similar to the "Dual Use Logistics Facility" except that it would include secret access agreements and covert development of commercial facilities to support later military use, with the ultimate objective of being able to support major combat operations against India and to dominate the IOR (Yung, 2015).

The theory about the Chinese "String of Pearls" is related to Beijing's need for geostrategic security of the "choke points" and maritime [oil and trade] routes critical of its development (Bozhev, 2019). It is designed to build infrastructure projects covering the Chinese SLOCs (Кувалдин, 2015), and based on China's need to establish an increased level of influence and advanced presence along the

\footnotetext{
${ }^{4}$ One of the six NSR economic corridors included in the EBSR is the China-Pakistan Economic Corridor (CPEC) that will extend the Karakoram Highway; it has already crossed the mountains between China and Pakistan building highway and railway links all the way through Pakistan to the port of Gwadar.

${ }^{5}$ Bangladesh-China-India-Myanmar Economic Corridor (BCIM-EC) is a sub-regional cooperation that aims to introduce new impetus to economic and social development by linking the southwestern parts of China with the northeastern region of India and the Bay of Bengal through Yangon and Mandalay in Myanmar, and Bangladesh. Although BCIM-EC was initiated long before the inception of BRI, China later incorporated it under BRI platform as one of the six economic corridors. Bangladesh-China-India-Myanmar Economic Corridor (BCIM-EC) consists of rail and road constructions, and industrial parks.
} 
sea routes through the use of investment ${ }^{6}$, port development, economic, political, diplomatic, and military means (Devonshire-Ellis, 2009).

In reality China's development of the MSR has made it an Indian Ocean power even without a blue water navy, capable of projecting power across the Indian Ocean or a collection of overseas bases. Initially described by Western analysts as a "String of Pearls" strategy, the announcement of the MSR in 2013 gave greater clarity as to what China had been doing: it built or funded expansion of ports and facilities across the Indian Ocean in a " "places' as opposed to bases" strategy in which China secured access to partner states' ports and naval facilities (Fulton, 2018, p. 179).

In fact, the "String of Pearls" concept is often viewed as a military initiative, with the aim of providing China's navy access to a series of ports stretching from the South China Sea to the Arabian Sea and oil-rich ME region (Harutyunyan, 2017, p. 95-102).

\title{
III. MENA as an Important Hub for the BRI
}

The "String of Pearls" strategy provides a forward presence for China along the sea lines of communication that now anchor China directly to the MENA region. It is an important hub for the two OBOR routes - EBSR and $M S R$ - due to its strategic location at the intersection of land and sea roads connecting Asia, Africa, Europe (BBC, 2015), and the three most important economic maritime regions:

\author{
the South China Sea; \\ the Persian Gulf; \\ the Mediterranean Sea (Matar, 2018).
}

The MENA region is also important to the MSR because of the inclusion of maritime chokepoints for energy transportation, such as:

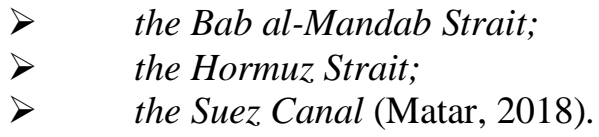

It is known that the oil transported through the Malacca Strait towards East Asia is three times the amount transiting the Suez Canal and fifteen times the amount passing through the Panama Canal. Approximately $90 \%$ of the Chinese oil imports coming from Africa and the ME in 2016 were delivered along this route (Bozhev, 2019). The China-run Gwadar Port in Pakistan reduces distances between East African and Persian Gulf ports to western China by more than four times the distance between eastern China and these regions via the Malacca Strait and Indonesia (Zenn, 2015, p. 10).

Beijing expands its presence along the Indo-Pacific Sea Route connecting the Strait of Malacca with the Suez Canal and, consequently, the Mediterranean Sea, where Chinese companies provide their presence or control in ports and terminals (United Arab Emirates (U.A.E.), Saudi Arabia, Egypt, Algeria, Turkey, Israel, Djibouti, etc.) through the acquisition, construction, modernization, expansion and operation to serve commercial and military interests (Linden, 2018, p. 4; Al-Tamimi, 2017, p. 2).

To ensure reliable access for Chinese commercial shipments from the Red Sea to the Mediterranean, Beijing has adopted a dual-track approach while expanding its interests in the Suez Canal corridor and following the land route through Israel (Scott, 2014, p. 10). China Harbor is building a new port next to Ashdod's existing one, and the Shanghai International Port Group (SIPG) has won a 25-year license to operate another deep-sea private port planned in Haifa. One long-term plan, that Israel hopes China could participate in, is building a railroad connection between the port of Eilat and the port of Ashdod, connecting the Red Sea to the Mediterranean Sea, thereby providing a safe

\footnotetext{
${ }^{6}$ China's investments extend from Hainan Island in the South China Sea, through the littorals of the Straits of Malacca, including port developments in Chittagong in Bangladesh; Sittwe, Coco, Hianggyi, Khaukphyu, Mergui and Zadetkyi Kyun in Myanmar; Laem Chabang in Thailand; and Sihanoukville in Cambodia. They extend across the Indian Ocean, Sri Lanka, the Maldives, Pakistan's Gwadar Port, and in islands within the Arabian Sea and into the Persian Gulf.
} 
alternative to the Suez Canal, and creating an inland trade and logistics center for Chinese trade between Asia and Europe (Pevzner, 2017).

The MSR puts Egypt at its center because of the Suez Canal and the megaproject for the construction of a parallel two-channel canal. Located at the meeting place of three continents, Egypt could become the capital of the NSR (Sharma, 2019, p. 10). In 2008, COSCO Pacific, China's largest shipping state-owned enterprises (SOE), invested US \$ 185.6 million in a joint venture to operate and manage the Suez Canal Container Terminal (SCCT) in Port Said East Port. State-owned China Harbor Engineering Company (CHEC) also completed a contract valued at US \$ 1 billion to construct a quay in al-Adabiya port (Egypt) at the southern entrance to the Canal. China proceeded with a US \$416 million investment in a second contract, for the construction of a cargo terminal at al-Adabiya port. Beijing is also considering the Suez Canal Regional Development Project (SCRDP), which includes the addition of a parallel channel to the Canal, as well as the construction of sub-sea tunnels under the Canal. Zhenhua Port Machinery Company, a subsidiary of China's state-owned Communication Construction Company (CCCC), secured a large-scale infrastructure project for U.A.E.'s Dubai Port World Sokhna under development alongside the China-Egypt special economic zone on the Gulf of Suez (Scott, 2014, p. 11-12).

Tehran is also a key node in China's overland and MSR, with Beijing looking to increase railway links and perhaps even establish a naval base on one of Iran's islands (Lin, 2011, p. X). The location of the Chabahar port (in southeastern Iran, on the Gulf of Oman) in the direction of the International North-South Transport Corridor (INSTC), thus, transit relations between Russia, Eastern Europe, Central Asia and the Caucasus, on the one hand, and Southeast Asia, the Far East, the countries of Oceania and the Persian Gulf, on the other, are seen as a significant advantage for Iran's participation in the Chinese BRI (Pars Today, 2019). However, Chabahar port is very close to Gwadar port in Pakistan which is developed by the Chinese as a part of the CPEC: this may lead to economic rivalry within the BRI between the two ports (Garlick, Havlova, 2020, p. 14).

China ceased investing in Syria immediately after the outbreak of its civil war, despite Syria's role as Jordan's maritime gateway to the Mediterranean and as a land bridge between Turkey and Jordan (Evron, 2020, p. 2). However, Syrian ports at Tartus and Latakia, both currently Russian bases, have been earmarked as major departure points for Chinese goods entering Europe (Blanche, 2017). OBOR will inevitably feature a Syrian hub - complete with the requisite legal support for Chinese companies involved in investment, construction and banking (Escobar, 2017). There is talk now that Tripoli (Lebanon) could even be a terminal in China's NSR project, carving a trade route from East Asia to Europe (Issa, 2017). On the Gulf of Oman, in 2014, privately owned Khorfakkan Container Terminal (KCT) received the first vessel of China Shipping Container Lines' (CSCL) expanded joint service with the United Arab Shipping Company (UASC) (Scott, 2015, p. 14). The two carriers have signed a number of joint service agreements over the past few years connecting Asian ports with ports in the ME and Europe (Sharjah Update, 2014).

The 3000-km long CPEC land transport corridor should connect Xinjiang (China) to the Arabian Sea through the Pakistani Kashmir in the port of Gwadar, linking the maritime and overland Silk Roads and developing not only its commercial value, but also its potential as a naval outpost overlooking Gulf shipping lanes (Chellaney, 2015). ${ }^{7}$

From the east coast of China, the ships follow the South China Sea to the Straits of Malacca, from where they are sent to the shores of northern and northeast Africa to reach the Israeli ports via the Bab el-Eilat and Ashdod - bypassing the Suez Canal. The further route involves the interconnection of trade routes with Istanbul (where railway tunnels are already running along the bottom of the Bosporus), Athens (Greece), Naples (Italy), Marseilles (France), and other Mediterranean cities that are part of the euro area (CypLIVE, 2017).

In April, 2016, COSCO secured a controlling share over the port of Piraeus in Greece. Other companies have holdings in seaports in Egypt (Alexandria, Adabiya, Port Said), in Algeria (Cherchell), in Turkey (Amberley), and in Italy (Genoa and Naples) - all of them arguably form part of China's OBOR strategy (Feder, 2016). From a military point of view, the addition of a new "pearl" in the

\footnotetext{
${ }^{7}$ CPEC, US $\$ 46$ billion project, will allow Beijing to shorten the route of its oil imports from the ME and Africa to barely one quarter of the current 12,000 km. The oil will be offloaded at Gwadar for transport by pipeline to western China.
} 
Mediterranean Sea in the form of the Greek sea port of Piraeus allows China to control maritime access to Istanbul and the Black Sea ports of Bulgaria, Romania, Ukraine, southern Russia and Georgia (Lin, 2011, p. 10).

It is also planned to combine the construction and operation of China's stable developing four large industrial parks in Egypt, the U.A.E., Saudi Arabia and Oman with neighboring ports, including the Khalifa port in Abu Dhabi, the port of Djibouti and the port of Said from Egypt and others, to create an "industrial park - port interconnection" (Harutyunyan, 2019, p. 33). As the third largest re-export hub in the world after Singapore and Hong Kong, approximately $60 \%$ of China's trade passes through Dubai's Jebel Ali Free Zone (Jafza), the world's largest free zone, and Jebel Ali port for re-export (Scott, 2015, p. 12). It is worth noting that announced during the 2018 Ministers' Meeting of the ChinaArab States Cooperation Forum (CASCF) in Beijing, the 'Industrial Park-Port Interconnection, TwoWheel and Two-Wing Approach' is a framework for connecting Chinese built industrial parks in key GCC cities with regional ports, creating a regional MSR network and establishing a hub that links other important MSR regions such as South Asia and East Africa (Fulton, 2019, p. 2). ${ }^{8}$

\section{Chinese Military Expansion in the MENA Region}

As it can be noticed from what was stated above, China hopes to contribute to strengthening regional security on the southern gateway from the Indian Ocean to the Red Sea and the Suez Canal, one of the world's biggest shipping lanes and a pivotal part of the MSR (Barisitz, Radzyner, 2017, p. 24). Today the Chinese energy security policy has been militarized by creating a navy and deploying troops to protect and implement energy and infrastructure projects in the MENA region.

And since China has limited resources of hard power, due to the fact that the country is not part of military alliances and did not have a military presence in the MENA, Beijing is trying to expand its influence through the use of soft power resources, creating new military bases in Africa and in ME and is actively developing the naval forces (Mao, 2007, p. 124). It will help China increase the frequency of PLAN operations in the region and multiply the number of Chinese ships passing through the waters of the Horn of Africa and the Arabian Peninsula (Panda, 2015).

Chinese permanent military presence overseas takes three main forms:

$\begin{array}{ll}\checkmark & \text { Escort fleet in the Gulf of Aden; } \\ \checkmark & \text { Navy technical service stops; } \\ \checkmark & \text { Peacekeeping forces in the ME (Sun, 2015). }\end{array}$

After China conducted its first operation outside the PLAN under the auspices of the anti-piracy mission in the Gulf of Aden in 2008, it became apparent that these operations (and subsequent logistical problems) were too large and spanning in areas just for the supply of fuel and food to the armed forces and civilians thousands of kilometers from the Chinese coastal waters. These new missions, called "military operations other than war" (MOOTW), could also include tasks such as peacekeeping, humanitarian aid and disaster relief operations, as well as maintaining internal stability operations (Marantidou, 2014, p. 3).

From 2009 to 2015, China sent 19 naval escorts to the Gulf of Aden and Somali waters, which visited Djibouti, Kenya, Oman, Saudi Arabia and Pakistan (Sun, 2015). In 2014, China sent the PLAN's $17^{\text {th }}$ and $18^{\text {th }}$ naval escort taskforces consisting of various amphibious landing ships, missile frigates and supply vessels to the Gulf of Aden, and the PLAN's $19^{\text {th }}$ naval escort taskforce sent to Somalia, also in April 2015, the $20^{\text {th }}$ task force was sent (Panda, 2015).

Chinese United Nations (UN) peacekeeping forces in the MENA consist of 1,152 personnel:

UN Truce Supervision Organization (2 observers);

- UN Interim Force in Lebanon (343 soldiers);

- UN Mission in the Republic of South Sudan (444 soldiers, 18 police, and 12 military

observers);

\footnotetext{
${ }^{8}$ A project titled as "industrial park-port interconnection, two-wheel and two-wing approach" cooperation layout, will allow Chinese industrial parks (free trade zone (FTZ) to create business clusters and increase trade flows.
} 
Chinese Navy interim technical service stops in the MENA can be categorized into three types:

\begin{abstract}
* for ship fuel and material resupply, such as stops in the ports of Djibouti (Djibouti), Aden (Yemen), Jeddah (Saudi Arabia), Salalah (Oman), and Sudan;

* for relatively fixed supply ship berthing and fixed-wing reconnaissance aircraft takeoff and landing, as a stop in the Seychelles, which are based on short-term agreements;

- stops that allow for a complete recharge to rest weaponry and take advantage of a large ship repair center, such as the stop in Pakistan, which is based on a long-term agreement (Sun, 2015).
\end{abstract}

Salalah - a logistics point of the first category provides refueling of Chinese ships. Aden belongs to the item of logistics of the second category and it is a large naval base (previously used in this capacity by Great Britain and later by the Soviet Union). It has 16 berths, provides basing of ships up to and including the destroyer (Храмчихин, 2017). China's Navy increasingly uses the deep-water Omani (considered a U.S. pro) port of Salalah on the Arabian Sea as a refueling and replenishing base during its anti-piracy operations (Molavi, 2018).

Chinese warships use ports in Yemen to replenish supplies. Moreover, in December 2009, Beijing announced its intention to establish a permanent naval base in the Gulf of Aden/Arabian Sea (Lin, 2011, p. 11). The most likely option is the Yemeni port of Aden than other alternatives - Oman and Djibouti - which have close ties with NATO and Washington (Al-Rawashdeh, AL-Qatatsheh, 2017, p. 41).

In Sudan, Chinese bases have been deployed for the navy and for the ground forces of the People's Liberation Army (PLA) and the PLA Air Force (Храмчихин, 2017). In July, 2015, the UN invited China to dispatch a peacekeeping infantry battalion to join the UN mission in South Sudan in order to protect civilians and UN personnel and facilities while conducting humanitarian rescue operations and helping the Intergovernmental Authority on Development (IGAD) in supervisory and inspection missions. This time China is sending out an entire infantry battalion for international peacekeeping, whereas previously China's peacekeeping forces were only comprised of an engineering unit, a transportation unit, a medical unit, and a guard unit (Zhang, 2015).

First overseas "military base": The "String of Pearls" strategy ends in the logistics point of the third category in the port of Djibouti (Djibouti, the "Gate to the Red Sea"), opened in July 2017 (Храмчихин, 2017). China calls the first overseas "military base" as a support base for escorting, peacekeeping, humanitarian aid, and search-and-rescue humanitarian operations in MENA (Gao, 2017; Headley, 2018). Djibouti is the first place in the world where China created its foreign full-fledged Chinese military base (for logistical facilities geared for naval rest and supply) outside the PRC (except for objects on the disputed islands of the South China Sea). It is the only place in the world where the American and Chinese military are literally face to face (the only U.S. military base in Africa) (Алиханов, 2017). Although this strategy is primarily aimed at connecting the Horn of Africa with the IOR and the South China Sea, the Djiboutian hub can also ensure the development of this strategy in the Mediterranean Sea (via the Suez Canal) and the further moving south along the African East Coast, reaching the South Africa (Sterioti, 2017, p. 2).

Regarding the fight against pirates, it should be noted that since the Strait of Singapore and the Strait of Malacca (parts of the MSR) are the busiest trade routes, they are the epicenters of piracy. And if even more cargo is delivered via MSR routes, then theoretically combining pirates will become easier, threatening security for the implementation of BRI (ISDP, 2016, p. 6). Thus, Beijing has become a larger security player in the wider region, and China's naval forces are engaged in the fight against piracy in the Horn of Africa (Lyall, 2019). In 2008, elements of the Chinese Navy in Somali waters launched joint anti-piracy exercises (Sun, 2015). In the Gulf of Aden, a Chinese frigate succeeded in preventing Somali pirates from assaulting an U.A.E.-owned oil tanker in April 2017 (Ardemagni, 2018, p. 11). Nevertheless, the deployment of China "security guards" to protect BRI projects opens a new element of the deployment of troops abroad - a feature that calls into question the Chinese basic foreign policy principle of non-interference (Kondapalli, 2019). 
However, the "String of Pearls" strategy or the "Dual Use Logistics Facility" model can be most appropriate for supporting China's future Indian Ocean operations, to address non-traditional security challenges. It would alleviate the burden of logistical support to China's overseas maritime operations (currently primarily anti-piracy operations), but could expand to support limited operations to protect Chinese citizens and property abroad. This may include the non-combatant evacuation operations (NEOs) of Chinese citizens, humanitarian and disaster relief operations, and possibly ground operations by special forces in places like Africa to protect Chinese personnel, property, and other economic interests (Yung, 2015).

\section{Chinese Military Expansion in IPR and MENA: Reason for Counteraction or Collaboration between Regional Players}

Currently, there are two main points of view on the role of China in MENA and IPR, and its implications for the foreign policy of the U.S., India, and other regional players. Some believe that China's actions in MENA and IPR are aimed at expanding Chinese power and influence at the expense of other regional powers in the area, which could ultimately lead to a conflict between them. The second opinion is that China's growing role in MENA will contribute to the greater interdependence and cooperation between the U.S., Iran, China, and other regional players, which will benefit all parties (Saito, 2007, p. 3).

In fact, China's strategic move to the IOR through the Horn of Africa has raised serious concerns about its military expansion in the region. The long-term Chinese military presence in Djibouti, Gwadar, and other ports of the Arabian Sea and the Indian Ocean, which can also serve as stops for the expansion of the Navy of the PLAN, create problems for Delhi, Washington, and other regional powers. The U.S. is concerned about China's growing global military presence, while India is concerned about China's ability to project its power in the Indian Ocean without hindrance (Panda, 2015; Molavi, 2018).

Since the economic center of gravity in the world is now concentrated around China and Asia in a broader sense, the Chinese will seek to attract investment from MENA, especially from the energyrich monopolies of the Persian Gulf. Naturally, these factors will encourage the Chinese (and possibly other participants in Asia, such as India) to be more persistent in defending their national interests in the region (Politikan.com.ua, 2013).

Therefore, Beijing is fully aware of the possible negative reaction that China's BRI and growing economic and military might cause in the international community, and how the perception of the "Chinese threat" could damage Beijing's image. The Chinese understand that without an effective solution to this problem of the "Chinese threat" in the U.S. and its neighboring countries, this growth will not be well accepted by the international community as a whole (Harutyunyan, 2016, p. 222-223). The "Chinese threat" approach to the Indo-Pacific region was also evident in the statements of U.S. officials in the Trump administration, as well as in the National Security Strategy (NSS) in December 2017. And if the U.S. approach to the Indo-Pacific region continues to be formed as a means of confronting China, the states and regions of Eurasia and the Indian Ocean can expect a new set of international political challenges, since different views on the Asian order lead to competition between the great powers, and the Persian Gulf region probably will participate in this competition (Fulton, 2018, p. 176). In this regard, to dispel concerns over China's strategic foot-forward in the IOR via the Horn of Africa and the "Chinese threat", Beijing downplayed the base's military-strategic importance by calling it a "support base for supply missions to carry out support, peacekeeping and humanitarian assistance missions in Africa and West Asia" (Jash, 2018, p. 72). Justifying this goal, the Chinese Foreign Ministry said that since 2008, China had been deploying ships in the Gulf of Aden and waters off the coast of Somalia on escort missions. Strongly opposing the name Djibouti as a military outpost built as a base for the Chinese military presence and strengthening its deterrent role in the IOR, Beijing argues that Djibouti acts as logistical support for replenishing food and fuel. However, this move by China reflects a shift in its foreign policy, as it contradicts its own commitment to the principle of "noninterference" and confirms Beijing's pragmatic drift from Deng Xiaoping's dictum of "maintaining a low profile" (Jash, 2018, p. 72).

Meanwhile, it is worth noting that China avoids countering other players in the region, especially the United States. Although China is expanding its navy on the military front, it is far from 
becoming a major naval power on a scale that could challenge or oust the United States (Calabrese, 2005, p. 4). Beijing takes advantage of the American security umbrella in the Persian Gulf - the U.S. Navy, which protects sea routes for barrels of oil, which mainly go to Asia, not to the West (Molavi, 2018). Moreover, the U.S. and China conducted their joint counter-piracy exercise in the Gulf of Aden in December 2014, which brought together 700 American and Chinese naval personnel. The U.S. Navy (USN) and PLAN conducted extensive training on search and seizure protocol and aimed to improve communication between the two navies (Washington, 2017). In addition, the dissatisfaction that Donald Trump expressed about the disproportionate dependence of the international community on the U.S. to preserve the freedom of navigation on critical sea lanes and the long-term protection of shipping routes to other countries with zero compensation, may even be taken as an invitation to step up PLAN activities in the western Indian Ocean, the Gulf of Aden, and the Persian Gulf (Panda, 2019).

Some experts even believe that the U.S. needs to create an integrated regional security structure in the Persian Gulf or the ME as a whole, so that it as a forum could attract China to a more responsible position in the MENA. Otherwise, a clash of interests could jeopardize the achievement of U.S. goals in the region and fuel a more general and undesirable antagonism between the U.S. and the world's fastest-growing power (Leverett, Bader, 2005-06, p. 199).

\section{Conclusion}

China's behavior with a cautious strategy based on increasingly developing maritime capabilities is part of its great strategy of dominating world trade transit and expanding territorial seas, as well as implementing a strategy that supports greater access to marine resources. "String of Pearls" not only gives China a safe route for energy, commerce and shipping, but also allows China to deploy its security and intelligence forces throughout the IPR, IOR and MENA. In fact, the "String of Pearls" strategy can not only allow China to change the balance of power at the regional level, but also have an impact that goes far beyond its traditional sphere, achieve global hegemony and put China in a dominant position in Asia, Africa, and Europe, mainly due to strategic control over the main points along the Chinese "String of Pearls" and new opportunities for the deployment of combat operational groups. Most likely, the Chinese expansion will grow steadily and its military presence will grow in order to protect its interests and ensure the safety of Chinese multi-billion-dollar investment in infrastructure projects across the width of the "String of Pearls". Here it is appropriate to cite the parallels of Ruslan Alikhanov drawn between the "String of Pearls" strategy and the games of Chess and Guo. He finds that Chess is taught to focus on calculating multi-way combinations in order to completely defeat the enemy: the pieces disappear from the board, leaving room for the winner. While Chess serves the idea of absolute superiority and complete defeat of the opponent, Guo (which means "game of environment", one of the four pillars of classical education) teaches players the concept of the strategic environment of the enemy, as well as relative superiority and does not allow strategic emptiness: the pieces remain on the board, but lacking the ability to maneuver. In fact, China, with its economic and financial capabilities, can achieve this goal by filling in the vacuum that could be created by the U.S. rejecting its international obligations.

REFERENCES:

Алиханов, Р. (2017)

Кувалдин, С. (2015)

Храмчихин, Ал. (2017)
Го, порты и деньги. Зарисовки о фактической стратегии Китая.//Forbes. <https://www.forbes.ru/biznes/346307-go-porty-i-dengi-zarisovki-ofakticheskoy-strategii-kitaya> (24.07.2017). (Alikhanov, $R$. Go, porty i den'gi. Zarisovki o fakticheskoy strategii Kitaya. // Forbes. $<$ https://www.forbes.ru/biznes/346307-go-porty-i-dengi-zarisovki-ofakticheskoy-strategii-kitaya> (24.07.2017)

Китайская подводная лодка зашла в Карачи. // Газета.Py. <https://www.gazeta.ru/politics/2015/07/01_a_6862685.shtml> (01.07.2015). (Kuvaldin, S. Kitayskaya podvodnaya lodka zashla v Karachi. // Gazeta.Ru. <https://www.gazeta.ru/politics/2015/07/01_a_6862685.shtml> (01.07.2015)

Жемчужная удавка // Почта Полевая. <https://pochtapolevaya.ru/militaryanalytics/geopolitics/eastazia/659/a316629.html> (26.05.2017). (Khramchikhin, Al. Zhemchuzhnaya udavka // Pochta Polevaya. 
$<$ https://pochta-polevaya.ru/militaryanalytics/geopolitics/eastazia/659/ $\underline{\text { a316629.html }>26.05 .2017)) ~}$

Abeyagoonasekera, A. (2019) China's Growing Influence in the Indian Ocean: Implications for Sri Lanka and its Regional Allies. // Strategies for the Indo-Pacific: Perceptions of the U.S. and Like-Minded Countries, Hudson Institute, p. 48-51.

<https://www.academia.edu/41341222/Indo_Pacific_Strategy_

Hudson_Institute?email_work_card=view-paper>

Ardemagni, El. (2018)

Gulf Powers: Maritime Rivalry in the Western Indian Ocean. // ISPI Analysis, No. 32, Istituto per gli Studi di Politica Internazionale (Italian Institute for International Political Studies), p. 1-15.

<https://www.academia.edu/40197571/Gulf_Powers_Maritime_Rivalry_in_the _Western_Indian_Ocean>

Barisitz, S.,

A. Radzyner (2017)

BBC (2015)

BDO (2015)

Blanche, E. (2017)

Bozhev, V. (2019)

Calabrese, J. (2005)

The New Silk Road, Part I: A Stocktaking and Economic Assessment. // Focus on European Economic Integration Q3/17, Oesterreichische Nationalbank (Austrian Central Bank), p. 8-30. <https://www.oenb.at/dam/jcr:48e8ae7a-e2c74a2b-af4a-a9cc22c0fbee/03_Barisitz_feei_3_17.pdf >

Is China-Pakistan 'Silk Road' a Game-Changer? // $B B C$.

<http://www.bbc.com/news/world-asia-32400091> (22.04.2015)

One Belt One Road - 带一路: What is “One Belt One Road”? - BDO, Singapore, p. 1-15. <http://www.bdo.com.sg/pub/pub_reports/BDO_One-BeltOne-Road.pdf>

China's New Silk Road Includes Both Risk and Promise of Prosperity. // The Arab Weekly. <http://www.thearabweekly.com/Economy/9902/China's-newSilk-Road-includes-both-risk-and-promise-of-prosperity> (17.12.2017)

The Chinese String of Pearls or How Beijing is Conquering the Sea. // De Re Military. <https://remilitari.wordpress.com/2019/08/26/the-chinese-string-ofpearls-or-how-beijing-is-conquering-the-sea/\#_ftnref8> (26.08.2019)

The Risks and Rewards of China's Deepening Ties with the Middle East. // China Brief, Vol.: 5, Issue 12, The Jamestown Foundation, p. 1-4.

<https://jamestown.org/program/the-risks-and-rewards-of-chinas-deepeningties-with-the-middle-east/>

Chellaney, B. (2015)

China Reinvents 'String of Pearls' as Maritime Silk Road. // Nikkei Asian Review. $<$ https://asia.nikkei.com/Politics/China-reinvents-string-of-pearls-as-MaritimeSilk-Road> (29.04.2015)

Clemens, M. (2015)

CypLIVE (2017)

Devonshire-Ellis, Ch. (2009)

The Maritime Silk Road and the PLA: Part One. // China Brief, Vol. 15, Issue 6, The Jamestown Foundation, p. 6-9. <https://jamestown.org/wpcontent/uploads/2015/03/China_Brief_Vol_15_Issue_6_3_01.pdf?x50873>

Turkey and Israel are Intercepted at Sea "Silk Road" of Iran. // CypLIVE. $<$ http://en.cyplive.com/ru/news/turciya-i-izrail-perehvatyvayut-u-iranamorskoy-shelkovyy-put.html> (12.03.2017)

China's String of Pearls Strategy. // China Briefing. <https://www.chinabriefing.com/news/china's-string-of-pearls-strategy/> (18.03.2009)

Escobar, P. (2017)

Evron, Y. (2020)

The New Silk Road Will Go through Syria. // Asia Times. <http://www.atimes.com/article/new-silk-road-will-go-syria/> (13.07.2017)

China's Involvement in the Levant: It's the Economy After All. //Asia Dialogue. $<$ https://theasiadialogue.com/2020/03/20/chinas-involvement-in-the-levant-itsthe-economy-after-all/> (20.03.2020)

Feder, R. (2016)

Fulton, J. (2018)

What China's New Silk Road Means for Israel. // Diplomatic Courier. $<$ https://www.diplomaticourier.com/chinas-new-silk-road-means-israel/> (01.09.2016)

The Gulf between the Indo-Pacific and the Belt and Road Initiative. // Rising Powers Quarterly, Vol. 3, Issue 2, p. 175-193.

<https://www.academia.edu/37560447/The_Gulf_between_the_IndoPacific_and_the_Belt_and_Road_Initiative>

Fulton, J. (2019)

Domestic Politics as Fuel for China's Maritime Silk Road Initiative: The Case of the Gulf Monarchies. // Journal of Contemporary China, p. 1-16. 
Gao, Ch. (2017)

Harutyunyan, Agh. (2016)

Harutyunyan, Agh. (2017)

Harutyunyan, Agh. (2019)

Headley, T. (2018)

ISDP (2016)

Issa, Ph. (2017)

Jash, A. (2018)

Khurana, G. S. (2018)

Kondapalli, S. (2019) <https://www.tandfonline.com/doi/abs/10.1080/10670564.2019.1637566?journ alCode $=$ cjec20>

China Officially Sets Up Its First Overseas Base in Djibouti. // The Diplomat. $<$ http://thediplomat.com/2017/07/china-officially-sets-up-its-first-overseasbase-in-djibouti/> (12.07.2017)

Garlick, J., R. Havlova (2020) China's "Belt and Road" Economic Diplomacy in the Persian Gulf: Strategic Hedging amidst Saudi-Iranian Regional Rivalry. // Journal of Current Chinese Affairs, p. 1-24.

<https://www.academia.edu/41808280/Chinas_Belt_and_Road_Economic_Dip lomacy_in_the_Persian_Gulf_Strategic_Hedging_amidst_Saudi-

_Iranian_Regional_Rivalry>

Chinese Peaceful Rise and Development. The Theory of "China's Threat". // The Countries and Peoples of the Near and Middle East, Vol. 30, IOS NAS RA, Yerevan, p. 216-227.

<http://orient.sci.am/files/publications/20170130_163840_am_UUUtd\%20\%20XXX\%20utunqlumlulu\%202017\%2097.pdf>

Chinese One Belt, One Road Initiative: Challenges and Opportunities. Mauritius: Lambert Academic Publishing, 288 p.

Chinese "Belt and Road" Initiative in the Middle East and North Africa. Россия-Китай: история и культура: сборник статей и докладов участников ХІІ Международной научно-практической конференции. Казань: Издательство «Фэн» АН РТ, - с. 29-37. (Harutyunyan Agh. Rossiya Kitay: istoriya i kul'tura: sbornik statey i dokladov uchastnikov XII Mezhdunarodnoy nauchno-prakticheskoy konferentsii. - Kazan': Izdatel'stvo «Fen» AN RT, - s. 29-37).

China's Djibouti Base: A One Year Update. // The Diplomat. <https://thediplomat.com/2018/12/chinas-djibouti-base-a-one-year-update/> (04.12.2018)

The Belt \& Road Initiative - 带 一 路. // Institute for Security and Development Policy (ISDP), p. 1-7. <http://isdp.eu/content/uploads/2016/10/2016-The-Beltand-Road-Initiative.pdf $>$

Lebanon Prepares for Syria's Post-War Construction Windfall. // Associated Press. $\quad<$ http://www.apnewsarchive.com/2017/Lebanon-seeks-jump-aboardwagon-of-Syria-s-reconstruction-boom-once-peace-arrives/id-

b3491b276c8446e3acf8e445890d3bac> (17.08.2017)

Djibouti: A Roadway to China's "Indian Ocean Dream". // Maritime Perspectives 2017, edited by Pradeep Chauhan and Gurpreet S Khurana, National Maritime Foundation, p. 72-74.

<https://www.academia.edu/36077372/Maritime_Perspectives_2017_Maritime _Developments_in_Indo-Pacific_Region_in_2017>

'Beyond Hardware and Technology': The Intangibles of China's Naval Power (Part 1). // Maritime Perspectives 2017, edited by Pradeep Chauhan and Gurpreet S Khurana, National Maritime Foundation, p. 196-205.

<https://www.academia.edu/36077372/Maritime_

Perspectives_2017_Maritime_Developments_in_Indo-

Pacific_Region_in_2017>

China's Belt and Road Initiative: From Arctic to Space: How China Plans to Expand its Global Footprints. // Financial Express.

$<$ https://www.financialexpress.com/defence/chinas-belt-and-road-initiativefrom-arctic-to-space-how-china-plans-to-expand-its-global-

footprints/1557484/> (24.04.2019)

Leverett, F., J. Bader (2005-06)Managing China-U.S. Energy Competition in the Middle East. - The Washington Quarterly, p. 187-201.

$<$ https://www.brookings.edu/wpcontent/uploads/2016/06/20051216_leverett_bader.pdf>

Lin, Ch. (2011)
The New Silk Road China's Energy Strategy in the Greater Middle East. - In: Policy Focus, No. 109, The Washington Institute for Near East Policy, p. 1-26. <https://www.washingtoninstitute.org/uploads/Documents/pubs/PolicyFocus10 9.pdf> 
Linden, H. R. (2018)

Lyall, N. (2019)

Mahan, A. Th. (2019)

Mao, Y. (2007)

Marantidou, V. (2014)

Matar, J. (2018)

Molavi, A. (2018)

Panda, A. (2015)

Panda, A. (2019)

Pars Today (2019)

Politikan.com.ua (2013) M. H. AL-Qatatsheh (2017)

Scott, E. (2014)

Scott, E. (2015)
Pevzner, A. B. (2017)

Al-Rawashdeh, M. S.,

Saito, H. T. (2007)

The New Sea People: China in the Mediterranean. // IAI Papers 18, Istituto Affari Internazionali (IAI), p. 2-21.

<https://www.iai.it/sites/default/files/iaip1814.pdf>

China's Rise in the Middle East: Beyond Economics. // The Diplomat. <https://thediplomat.com/2019/02/chinas-rise-in-the-middle-east-beyondeconomics/> (25.02.2019)

China's 'String of Pearls' Exhibits the Dragon's Great Game of Loans and Debts. // European Foundation for South Asian Studies (EFSAS), Amsterdam, p. 1-9. <https://www.efsas.org/China's\%20'String\%20of\%20Pearls'\%20exhibits\%20T he\%20Dragon's\%20Great\%20Game\%20of\%20Loans\%20and\%20Debts.pdf>

China's Interests and Strategy in the Middle East and Arab World. - In: Eisenman, J., E. Heginbotham and D. Mitchell (Eds.) China and the Developing. Armonk, M.E. Sharpe NY, p. 113-132.

Revisiting China's 'String of Pearls' Strategy: Places 'With Chinese Characteristics' and Their Security Implications. // Issues and Insights, Vol. 14, No. 7, p. 1-39.

<https://www.files.ethz.ch/isn/182061/140624_issuesinsights_vol14no7.pdf>

China's Rising Role in the Middle East: An Overview. // Meirss. $<$ http://meirss.org/chinas-rising-role-middle-east-overview/> (15.08.2018)

Enter the Dragon: China's Belt and Road Rising in the Middle East. // Hoover Institution or Stanford University, Issue 1819.

<https://www.hoover.org/research/enter-dragon-chinas-belt-and-road-risingmiddle-east> (02.10.2018)

A Naval Base on the Horn of Africa for China? // The Diplomat. $<$ http://thediplomat.com/2015/05/a-naval-base-on-the-horn-of-africa-forchina/> (13.05.2015)

Trump Wants China to Pick Up the Slack in the Strait of Hormuz. // The Diplomat. <https://thediplomat.com/2019/06/trump-wants-china-to-pick-up-theslack-in-the-strait-of-hormuz/?fbclid

=IwAR0AkgY0j2EusDfE2ST4gvXNtID3EVAYs6EzKPFc2cypvw7hWjxjdRO rPYk> (25.06.2019)

Значение Ирана в китайском проекте «Шелкового пуги» и транзитных коридорах в регионе. // Pars Today. <https://parstoday.com/ru/radio/programs-i99610> (19.03.2019). (Znacheniye Irana v kitayskom proyekte «Shelkovogo puti» i tranzitnykh koridorakh v regione// Pars Today. <https://parstoday.com/ru/radio/programs-i99610> (19.03.2019))

Payette, Al., T. (G.) Sun (2017) China's Two Ocean Strategy: Controlling Waterways and the New Silk Road. //Asia Focus \#31, Asia Programme, Institut de Relations Internationales et Stratégiques (IRIS), p. 2-22. $<$ https://www.academia.edu/33095104/CHINAS_TWO_OCEAN_STRATEGY_Controlling _waterways_and_the_new_silk_road $>$

China's 'New Silk Road' and the Middle East. // The Jerusalem Post. <http://www.jpost.com/Opinion/Chinas-New-Silk-Road-and-the-Middle-East490157> (08.05.2017)

China is Capable of Competing with the United States in the Middle East. // Politikan.com.ua. <http://politikan.com.ua/2/0/0/67789.htm> (23.06.2013)

China's Strategy in the Middle East (The Silk Road Project). // IOSR Journal of Humanities and Social Science (IOSR-JHSS), Vol. 22, Issue 1, Ver. 4, January, p. 37-51.

$<$ https://www.researchgate.net/publication/313320699_China's_strategy_in_the _Middle_East_The_Silk_Road_Project>

China's Expansion into the Middle East and its Effects on U.S. Foreign Policy. Thesis. // Naval Postgraduate School Monterey, California, 107 p.

$<$ https://calhoun.nps.edu/bitstream/handle/10945/3673/07Mar_Saito.pdf?seque nce $=1$ \&isAllowed $=\mathrm{y}>$

China's Silk Road Strategy: A Foothold in the Suez, But Looking to Israel. // China Brief, Vol. 15, Issue 19, The Jamestown Foundation, p. 10-14.

$<$ https://jamestown.org/wp-

content/uploads/2014/10/China_Brief_Vol_14_Issue_19_5.pdf?x71854>

China's "One Belt, One Road" Strategy Meets the UAE's Look East Policy. //

China Brief, Vol. 15, Issue 11, The Jamestown Foundation, p. 12-15. 


\section{Sharjah Update (2014)}

Sharma, A. (2019)

Sterioti, A. (2017)

Sun, D. (2015)

Szczudlik-Tatar, J. (2013)

Al-Tamimi, N. (2017)

Washington, B. (2017)

Yung, Ch. D. (2015)

Zenn, J. (2015)

Zhang, D. (2015)

Zhou, B. (2014)
<https://www.academia.edu/21339635/China_s_One_Belt_One_Road_Strategy _Meets_the_UAE_s_Look_East_Policy>;

$<$ https://jamestown.org/program/chinas-one-belt-one-road-strategy-meets-theuaes-look-east-policy/>

Khorfakkan Port Receives New Container Service. // Sharjah Update. $<$ http://www.sharjahupdate.com/2014/08/khorfakkan-container-terminal-csclservice/> (20.08.2014)

An Analysis of 'Belt and Road' Initiative and the Middle East. // Asian Journal of Middle Eastern and Islamic Studies, p. 1-15.

$<$ https://www.tandfonline.com/doi/abs/10.1080/25765949.2019.1586179?journ alCode $=$ rmei20 $>$

The Significance of China's 'String of Pearls Strategy'. // International Business Transactions in the People's Republic of China, University of San Diego School of Law, p. 1-29.

<https://ssrn.com/abstract=2951903 or http://dx.doi.org/10.2139/ssrn.2951903> China's Soft Military Presence in the Middle East. // Middle East Institute. $<$ https://www.mei.edu/publications/chinas-soft-military-presence-middle-east> (11.03.2015)

China's New Silk Road Diplomacy. // Policy Paper, No. 34 (82), The Polish Institute of International Affaires (PISMP), p. 1-8.

<http://www.pism.pl/files/?id_plik=15818>

Belt \& Road initiative: The Middle East's Growing Role? // Al Arabiya English. $<$ http://english.alarabiya.net/en/views/news/middle-east/2017/05/17/Belt-Roadinitiative-The-Middle-East-s-growing-role-.html> (17.05.2017)

The Gulf of Aden Needs US-China Maritime Cooperation. // The Diplomat. $<$ https://thediplomat.com/2017/11/the-gulf-of-aden-needs-us-china-maritimecooperation/utm_content=buffer78390\&utm_medium= social\&utm_source=facebook.com\&utm_campaign=buffer $>(06.11 .2017)$ Burying China's 'String of Pearls'. // The Diplomat. <https://thediplomat.com/2015/01/burying-chinas-string-of-pearls/> (22.01.2015)

Future Scenarios on the New Silk Road: Security, Strategy and the SCO. // China Brief, Vol. 15, Issue 6, The Jamestown Foundation, p. 9-12.

$<$ https://jamestown.org/wp-

content/uploads/2015/03/China_Brief_Vol_15_Issue_6_4_01.pdf?x50873>

China Assumes International Responsibility by Dispatching Peacekeeping Infantry Battalion. // CCTV.com.

<http://english.cntv.cn/2015/01/15/ARTI1421304498270545.shtml>

(01.15.2015)

The String of Pearls and the Maritime Silk Road. // China and US Focus. $<$ http://www.chinausfocus.com/foreign-policy/the-string-of-pearls-and-themaritime-silk-road/> (11.02.2014) 